\title{
A quality of life assessment and the correlation between generic and disease-specific questionnaires scores in outpatients with chronic liver disease-pilot study
}

\author{
MILICA OBRADOVIC ${ }^{1}$, ZORAN GLUVIC ${ }^{1,2}$, NINA PETROVIC ${ }^{3}$, MILAN OBRADOVIC ${ }^{3}$, \\ RATKO TOMASEVIC ${ }^{1,2}$, PREDRAG DUGALIC $^{1}$, ESMA R. ISENOVIC $^{3}$ \\ ${ }^{1}$ Zemun Clinical Hospital, School of Medicine, University of Belgrade, Belgrade, Serbia \\ ${ }^{2}$ School of Medicine, University of Belgrade, Belgrade, Serbia \\ ${ }^{3}$ Institute of Nuclear Sciences Vinca, University of Belgrade, Laboratory of Radiobiology \\ and Molecular Genetics, Mike Petrovica Alasa 12-14, 11001 Belgrade, Serbia
}

\begin{abstract}
Introduction. Chronic liver diseases (CLD) are an important cause of morbidity and mortality in general population. The aim of this study was to analyze potential differences between patients with CLD and healthy control group, and to estimate the severity of CLD by using simple questionnaires: general health questionnaire (GHQ-12) and chronic liver disease questionnaire (CLDQ).

Methods. A cross-sectional pilot study was performed in Zemun Clinical Hospital during years 2014 and 2015. Sixty participants were divided into 4 groups (15 per group): chronic alcoholic hepatitis, other chronic hepatitis, liver cirrhosis, and healthy control group. Entire study population chose one of four offered answers of structured questionnaires GHQ-12 and CLDQ, based on which mean model of end-stage liver disease (MELD) and Child-Turcotte-Pugh (CTP) scores were calculated.

Results. Mean GHQ12 and CLDQ scores were 10.5 and $5.21 \pm 1.11$ respectively. Regarding certain CLDQ domain scores, a significant difference between alcoholic and non-alcoholic hepatitis groups in the worry domain was observed. Mean MELD score was $7.42 \pm 2.89$ and did not differ between chronic hepatitis groups, while mean CTP score was $5.73 \pm 0.88$. A statistically significant correlation was observed between GHQ12 and CLDQ scores $(\rho=-0.404, p<0.01)$, but not between subjective and objective scores.

Conclusions. Mean GHQ12 and CLDQ scores pointed out to general psychological no-distress condition of the studied participants, as well as scarcely expressed CLD-specific complaints. Mean MELD and CTP scores indicated stable chronic liver diseases, with low three-month mortality rates in the cases of chronic hepatitis, as well as determination to Child A group in the case of liver cirrhosis.
\end{abstract}

Key words: chronic hepatitis, liver disease, liver cirrhosis, quality of life, questionnaire.

\section{INTRODUCTION}

Chronic hepatitis is clinical syndrome of heterogeneous etiology, defined as liver inflammation, continuously lasting for six months. There are several causes of chronic hepatitis: hepatitis $\mathrm{C}$ virus (HCV) and hepatitis B virus (HBV) infection, medicamentous hepatitis, alcoholic and non-alcoholic steatohepatitis (NASH) [1].

Quality of life (QoL) is an individual perception of person's own life in the context of cultural and socially accepted value system, regarding the goals, standards, expectations and concerns, according to WHOQOL [2]. QoL measurement instruments can be classified into: a) general or generic, b) diseasespecific, and c) instruments measuring economic aspects of health and analyzing medical decision making (utility measures)[3]. Disease-specific questionnaires focus on individual perception of a patient [3].
The General Health Questionnaire (GHQ-12) is a general type questionnaire intended to assess current mental status of the patients in a variety of illnesses, including liver disease; it also represents a subjective assessment of the effects of the therapy [4].

Specific questionnaires are used for a particular disease, such as questionnaire for chronic liver disease (CLDQ) [5]. CLDQ is clinically more likely to be applicable, because it is significantly shorter and easier to understand than other similar questionnaires [6]. Although worse CLDQ score indicates greater severity to the liver disease, it does not have the ability to discriminate precisely the earlier from advanced stages of the liver disease [3]. CLDQ was authorized by Younussi et al. [7] and was adapted for use within the patients in Serbia [8]. Now, this questionnaire is widely used among clinicians. 
This study was performed in order to analyze potential differences between patients with CLD and healthy control, also to estimate the severity of CLD by using the scores obtained by GHQ12 and CLDQ questionnaires.

\section{MATERIALS AND METHODS}

A cross-sectional pilot study was performed in the Hepatology outpatient department of Zemun Clinical Hospital ( $\mathrm{ZCH})$. After the approval of the Ethics Committee of $\mathrm{ZCH}$, the patients voluntarily agreed to participate in the study. The methodology and objectives of the study were clearly explained to the participating respondents, and they signed informed consents. Respondents were recruited by the time of arrival to outpatient clinic, and clustered into subgroups according to the diagnosis of liver disease. After meeting the quota of 15 participants per group, a total of 60 , the recruitment of respondents for this pilot study was closed. All 60 participants were examined, divided into four groups (15 per group): first group included outpatients suffering from chronic alcoholic hepatitis, the second group was formed of outpatients with other chronic liver diseases (viral-HBV and HCV, nonalcoholic and medicamentous hepatitis), the third group consisted of outpatients with cirrhosis, while the fourth group was the healthy control group. CLD was diagnosed by histological criteria, or by the levels of serum aminotransferases that were
1.5 times higher than the upper limit of normal reference interval values for the duration of more than six months. Viral etiology of chronic liver disease has been confirmed by ELISA HBsAg, or ELISA anti HCV tests in the Transfusion Laboratory of $\mathrm{ZCH}$. The diagnosis of cirrhosis was based on patients' disease history, clinical, physical and laboratory parameters, abdominal ultrasound scan, and histological criteria [9]. The inclusion criterion was CLD, while the exclusion criteria were: first check-up of patients with chronic hepatitis after the hospitalization, liver malignancies, cardiac cirrhosis, decompensated cirrhosis, or acute complications of liver cirrhosis of any etiology (variceal bleeding, hepatic encephalopathy, acute liver failure). Patients with transplanted liver or any other organ, and with HIV co-infection, were excluded from the study.

In our study, we have used GHQ-12 as generic questionnaire, and CLDQ as disease-specific type of questionnaire. All participants were informed with a structured questionnaire (GHQ12 and CLDQ), and then we explained them how to fill the questionnaires (choosing one of the four answers offered). The data analysis was based on the rank transformation of chosen answers into numerical values with rising tendency- a standard (Likert) score [values 0, 1, 2 and 3] [10]. Maximal value of the standard score is 36 . A higher score indicates a higher degree of disturbance of the general health status $[4,10]$. Ranking within groups is presented in Table 1.

Table 1

General health questionnaire (GHQ12) scoring system

\begin{tabular}{ccc}
\hline GHQ12 score & Group & Description \\
\hline $0-15$ & 1 - normal & Without distress \\
$16-25$ & 2 - minor & Mild distress \\
$\geq 25$ & 3 - major & Severe distress \\
\hline
\end{tabular}

CLDQ consists of 29 questions, with 7 structured answers $(1$ - all the time present; 7 - never present). The greater the score, the number of annoyances is smaller, and vice versa. Score is composed of 6 domains, which have a different number of questions related to: abdominal symptoms (3 questions; the order of 1, 5, 17), fatigue (5 questions; the order of $2,4,8,11,13$ ), systemic symptoms (5 questions; the order of $3,6,21,23$, 27 ), the activity ( 3 questions; the order of $7,9,14$ ), emotional functioning ( 8 questions; the order of 10 , $12,15,16,19,20,24,26)$, as well as concerns (5 questions; the order of 18, 22, 25, 28, 29). The average score for each domain is equal to the sum of ranks for all issues related to this area, divided by the number of questions. Total CLDQ score is equal to the sum of scores of a particular domain divided by the total number of questions. Popovic et al. [8] have validated the questionnaire for our patients.

To assess the liver disease severity and survival rate, we used the mean model of end-stage liver disease (MELD) in the case of chronic hepatitis [11] and Child-Turcotte-Pugh score (CTP) for the liver cirrhosis [12]. Calculation of MELD score requires determination of serum bilirubin and creatinine levels, as well as International Normalized 
Ratio for Prothrombin Time (INR). MELD score was calculated using the following formula:

MELD $=3.78 \times \ln$ [bilirubin] $+11.2 \times \ln [$ INR $]+$ $9.57 \times \ln$ [creatinine] $+6.43 \times$ etiology

(0: holestatic or alcoholic, 1 - others)

Calculated MELD score was used to predict three-month mortality rates, as follows: $<9(1-9 \%)$, 10-19 (6\%), 20-29 (19, 6\%), 30-39 (52, 6\%), $\geq 40$ $(71,3 \%)[11]$. Values of the variables needed to calculate the CTP score [12] are presented in Table 2. On the morning after the questionnaires fulfilling, blood samples were taken from participants for measurement of creatinine, total bilirubin, albumin, prothrombine time, and determination of INRSerum creatinine was measured by Jaffe reaction, on the IL 650 analyzer (Instrumentation Laboratory, USA), expressed in $\mu \mathrm{mol} / \mathrm{L}$. The reference values are between 44 and $133 \mu \mathrm{mol} / \mathrm{L}$. Total bilirubin was determined by diazo method, expressed in $\mu \mathrm{mol} / \mathrm{L}$, with the reference values from 4.96 to $23.36 \mu \mathrm{mol} / \mathrm{L}$. Serum albumin levels were determined by bromocresol method, on the same analyzer, expressed in $\mathrm{g} / \mathrm{L}$, with the reference values $35-55 \mathrm{~g} / \mathrm{L}$. Prothrombin time was determined by the IL analyzer
ACL Elite Pro (Instrumentation Laboratory, USA), expressed in seconds. INR is the ratio of the participants' and healthy witness' prothrombin time and it is expressed as a decimal number. The normal value is 1.00 . MELD score evolved from 3 months-mortality prediction score in TIPS patients to scoring system for assessing the severity of chronic liver diseases. Nowadays, it has a role in priority recruitment of liver transplant recipients by Eutransplant and UNOS. Thus, MELD has been recognized as a major contribution to the daily practice of hepatology [11]. To overcome some limitations, an improvement could be made in the future (for example, introduction of sodium and renal function analyses).

Demographic parameters (gender, age, marital and educational status, occupation) and medical history (risk factors for liver disease, HBV vaccination, family burden, the duration of liver disease, number of hospitalizations due to a liver disease, and number of cirrhosis decompensations) were analyzed, as well. Finally, the participants were asked about the overall subjective feeling within the past two months, with structured answers analyzed in Table 3.

Table 2

Variables and calculating the Child-Turcotte-Pugh (CTP) score (sum of numerical values for 5 variables)

\begin{tabular}{cccc}
\hline Variable & 1 point & 2 points & 3 points \\
\hline Total bilirubin $(\mu \mathrm{mol} / \mathrm{L})$ & $<34$ & $34-50$ & $>50$ \\
Serum albumin $(\mathrm{g} / \mathrm{L})$ & $>35$ & $28-35$ & $<28$ \\
PT $-\mathrm{INR}$ & $<1.7$ & $1.71-2.30$ & $>2.30$ \\
Ascites & none & mild & moderate to expressed \\
Encephalopathy & none & I-II degree & III $-I$ degree \\
& & (or suppressed by medicine) & (or refractory) \\
\hline
\end{tabular}

PT-INR - Prothrombin Time - International Normalized Ratio

Table 3

Value of Child-Turcotte-Pugh (CTP) score, class affiliation, and survival

\begin{tabular}{cccc}
\hline Scores & Class & One-year survival & Two-year survival \\
\hline $\mathbf{5 - 6}$ & $\mathrm{A}$ & $100 \%$ & $85 \%$ \\
$\mathbf{7 - 9}$ & $\mathrm{B}$ & $81 \%$ & $57 \%$ \\
$\mathbf{1 0 - 1 5}$ & $\mathrm{C}$ & $45 \%$ & $35 \%$ \\
\hline
\end{tabular}

\section{STATISTICAL ANALYSIS}

In the data analysis, we used measures of central tendency (median and mean values), and variability measures (standard deviation and coefficient of variation) were used. To assess the normality of the data distribution, Kolmogorov-Smirnov test was used. Also, Spearman's rank correlation test for potential nonparametric correlations was used. As far as potentially significant differences, chi- square test was used for categorical data, and nonparametric Mann-Whitney test to examine the differences between two groups with continuous variables that do not follow normal distribution. For the three group comparison, we used parametric and non-parametric-factor analysis of variance (ANOVA / LSD test posthoc- / and Kruskal-Wallis test). $\mathrm{P}$ values $<0.05$ were considered as significant. Statistical package SPSS for Windows 17.0 (SPSS Inc., Chicago, Illinois) was used. 


\section{RESULTS}

The study included 60 participants with the mean age of $60 \pm 11$ (26-84) years, (Table 4). Of all participants, $38(63 \%)$ were male, and the frequency distribution significantly differed between groups formed according to gender $\left(\chi^{2}=18.660\right.$, $\mathrm{p}<0.01$ ) (Table 4). The average duration of liver disease significantly differed among the groups $\left(\chi^{2}=10,990 \mathrm{p}<0.01\right)($ Table 4). GHQ12 average score was 10.5 (2-26), with no significant differences among the examined groups (Table 4). Average MELD score for the participants with chronic hepatitis was $7.42 \pm 2.89$ (6.00-21.00), and no significant differences among subgroups with chronic hepatitis were observed (Table 4). Average CTP score for the group with compensated cirrhosis was $5.73 \pm 0.88$ (5.00-8.00) (Table 4).

Table 4

Summarized data by the groups

\begin{tabular}{|c|c|c|c|c|c|}
\hline \multicolumn{2}{|c|}{ Variable } & $\begin{array}{l}\text { Group 1 } \\
(n=15)\end{array}$ & $\begin{array}{l}\text { Group 2 } \\
(n=15)\end{array}$ & $\begin{array}{l}\text { Group 3 } \\
(n=15)\end{array}$ & $\begin{array}{l}\text { Group } 4 \\
(n=15)\end{array}$ \\
\hline \multicolumn{2}{|c|}{ Gender $[\widehat{\partial}(\%)]$} & $14(93)$ & $6(40)$ & $13(87)$ & $5(33)$ \\
\hline \multirow{2}{*}{\multicolumn{2}{|c|}{$\begin{array}{c}\text { Age } \\
{[\mathrm{X} \pm \mathrm{SD}(\min -\max )]}\end{array}$}} & $56 \pm 12$ & $59 \pm 11$ & $65 \pm 6$ & $60 \pm 15$ \\
\hline & & $(38-75)$ & $(35-84)$ & $(56-74)$ & $(26-70)$ \\
\hline \multicolumn{2}{|c|}{$\begin{array}{c}\text { disease } \\
{[\operatorname{Med}(\min -\max )]}\end{array}$} & $1(1-7)$ & $6(1-22)$ & $3(1-16)$ & \\
\hline \multicolumn{2}{|c|}{ GHQ12 score } & $10(2-20)$ & $11(7-26)$ & $11(5-22)$ & $9(3-19)$ \\
\hline \multirow{3}{*}{$\begin{array}{c}\text { GHQ12 } \\
{[\mathrm{n}(\%)]}\end{array}$} & Normal & $14(93)$ & $12(80)$ & $10(67)$ & $13(87)$ \\
\hline & Minor & $1(7)$ & $2(13)$ & $5(33)$ & $2(13)$ \\
\hline & Major & 0 & $1(7)$ & 0 & 0 \\
\hline \multirow{11}{*}{$\begin{array}{c}\text { CLDQ } \\
{[\mathrm{X} \pm \mathrm{SD}} \\
(\min - \\
\max )]\end{array}$} & AS & $\begin{array}{c}5.49 \pm 0.96 \\
(3.00-7.00)\end{array}$ & $\begin{array}{c}4.64 \pm 1.59 \\
(2.33-7.00)\end{array}$ & $\begin{array}{c}5.78 \pm 1.15 \\
(4.00-7.00)\end{array}$ & $\begin{array}{l}4.87 \pm 1.57 \\
(2.67-7.00)\end{array}$ \\
\hline & $\mathrm{F}$ & $5.25 \pm 1.13$ & $4.61 \pm 1.44$ & $5.16 \pm 1.34$ & $4.87 \pm 1.18$ \\
\hline & & (3.00-6.80) & $(1.00-7.00)$ & $(2.80-6.60)$ & $(2.80-7.00)$ \\
\hline & SS & $\begin{array}{c}5.53 \pm 1.15 \\
(3.00-7.00)\end{array}$ & $\begin{array}{l}5.32 \pm 1.27 \\
(2.00-7.00)\end{array}$ & $\begin{array}{c}5.68 \pm 1.06 \\
(3.20-7.00)\end{array}$ & $\begin{array}{c}5.15 \pm 1.30 \\
(2.80-7.00)\end{array}$ \\
\hline & $\mathrm{AC}$ & $\begin{array}{c}5.87 \pm 1.12 \\
(3.33-7.00)\end{array}$ & $\begin{array}{c}5.04 \pm 1.60 \\
(1.00-7.00)\end{array}$ & $\begin{array}{c}5.95 \pm 0.97 \\
(4.33-7.00)\end{array}$ & $\begin{array}{l}5.44 \pm 1.56 \\
(2.33-7.00)\end{array}$ \\
\hline & $\mathrm{FE}$ & $5.34 \pm 1.02$ & $4.63 \pm 1.29$ & $4.99 \pm 1.09$ & $5.02 \pm 1.23$ \\
\hline & $\mathrm{EF}$ & $(3.25-6.88)$ & $(1.88-6.75)$ & $(2.88-6.38)$ & $(2.88-6.75)$ \\
\hline & W & $5.36 \pm 0.99$ & $4.23 \pm 1.76$ & $5.11 \pm 1.74$ & $5.87 \pm 1.14$ \\
\hline & W & $(3.60-7.00)$ & $(1.00-7.00)$ & $(1.00-7.00)$ & $(3.40-7.00)$ \\
\hline & & $5.47 \pm 0.86$ & $4.75 \pm 1.35$ & $5.44 \pm 1.05$ & $5.20 \pm 1.06$ \\
\hline & $\Sigma$ & $(3.61-6.71)$ & $(1.53-6.93)$ & $(3.48-6.63)$ & $(3.20-6.48)$ \\
\hline \multicolumn{2}{|c|}{$\begin{array}{c}\text { MELD score } \\
{[\mathrm{Med}(\mathrm{min}-\max )]}\end{array}$} & $7(6-9)$ & $7(6-21)$ & l & / \\
\hline \multicolumn{2}{|c|}{$\begin{array}{c}\text { CTP score } \\
{[\operatorname{Med}(\min -\max )]}\end{array}$} & I & / & $6(5-8)$ & / \\
\hline \multirow{3}{*}{$\begin{array}{l}\text { Feeling } \\
{[\mathrm{n}(\%)]}\end{array}$} & better & $1(7)$ & $3(20)$ & $3(20)$ & $6(40)$ \\
\hline & the same & $10(67)$ & $10(67)$ & $11(73)$ & $5(33)$ \\
\hline & worse & $4(26)$ & $2(13)$ & $1(7)$ & $4(27)$ \\
\hline
\end{tabular}

AS - abdominal symptoms; F- fatigue; SS - systemic symptoms; AC - activity; EF - emotional functions; W - worry; $\Sigma$ - total, GHQ-12 - general health questionnaire; CLDQ - chronic liver disease questionnaire; MELD - model of end-stage liver disease; CTP -Child-Turcotte-Pugh score.

Considering the occupation of participants, most of them were mechanic technicians - 23 (38\%), economists $-8(13 \%)$, traders $-5(8 \%)$, logistician $-4(7 \%)$. Professions related to medicine, health, education and housewives, referred to $-3(5 \%)$ of participants, while automechanic, agricultural and catering professions belonged to $-2(3 \%)$ of the participants, and other professions to the remaining $-5(9 \%)$ participants.

Within our cohort, 37 (62\%) of participants consumed daily or periodically alcoholic beverages.
Fifteen of them (47\%) used alcohol up to 25 years. Consumption of different alcoholic beverages referred to 20 (54\%) participants of this study, who preferentially used the following types of drinks: $17(46 \%)$ used strong alcoholic beverages, 15 (40\%) beer, and $5(14 \%)$ wine. Maximum daily consumption of strong alcoholic beverages was 11, 31 of wine and 3.51 of beer. None of them abused drugs intravenously, while $5(8 \%)$ of them had tattoos (four of them belonged to the subgroup of patients with alcoholic hepatitis, and one of them was from 
the subgroup of patients with non-alcoholic $(\mathrm{HCV}+)$ hepatitis. Three percent of participants were vaccinated against $\mathrm{HBV}$ infection. One of them was infected with $\mathrm{HCV}$ and had chronic hepatitis, while the other participant belonged to the control group.

Thirteen participants $(76 \%)$ had surgical procedure in the past (as potential risk to gain chronic liver disease due to an infection).

Liver disease was histologically confirmed in $4(9 \%)$ patients, a total of $13(22 \%)$ patients were hospitalized, and $10(17 \%)$ of participants had some of the manifestations of hepatic decompensation.

The frequency distribution of participants according to GHQ12 score modalities is presented in Table 5, and the total CLDQ and the scores of particular domains are presented in Table 6. Fig. 1 shows the frequency distribution of participants divided into groups according to the structured answers regarding general subjective emotional status for the past two months. There were no differences in participants' frequency distribution between GHQ12 score groups and groups formed according to structured answers regarding general subjective emotional status for the past two months $\left(\chi^{2}=2.627, p>0.05\right)$. Correlation coefficients between the scores that assess QoL and clinical scores for the estimation of the disease severity are shown in Table 7.

Table 5

Frequency distribution according to gradation of GHQ12 questionnaire

\begin{tabular}{cc}
\hline Gradation of GHQ12 score & n (\%) \\
\hline Normal & $49(82)$ \\
Minor & $10(17)$ \\
Major & 1 \\
\hline
\end{tabular}

Table 6

Cumulative CLDQ and scores by the domains in the examined population

\begin{tabular}{lccc}
\hline \multicolumn{1}{c}{ CLDQ } & Arithmetic mean \pm SD & Min-Max & p \\
\hline Abdominal symptoms & $5.19 \pm 1.39$ & $2.33-7.00$ & $\mathrm{~ns}$ \\
Fatigue & $4.97 \pm 1.27$ & $1.00-7.00$ & $\mathrm{~ns}$ \\
Systemic symptoms & $5.42 \pm 1.19$ & $2.00-7.00$ & $\mathrm{~ns}$ \\
Activity & $5.58 \pm 1.36$ & $1.00-7.00$ & $\mathrm{~ns}$ \\
Emotional functions & $4.99 \pm 1.16$ & $1.87-6.87$ & $\mathrm{~ns}$ \\
Worry & $5.14 \pm 1.53$ & $1.00-7.00$ & $<0.05^{*}$ \\
Total & $5.21 \pm 1.11$ & $1.53-6.92$ & $\mathrm{~ns}$ \\
\hline
\end{tabular}

*- alcoholic hepatitis $v s$. other hepatitis $<0.05$

Table 7

Correlation coefficients among scores in the examined population

\begin{tabular}{ccccc}
\hline $\begin{array}{c}\text { Correlation } \\
\text { coefficients }(\boldsymbol{\rho})\end{array}$ & GHQ12 & CLDQ & MELD & CTP \\
\hline GHQ12 & $/$ & $-0.404^{* *}$ & +0.377 & +0.024 \\
CLDQ & $-0.404^{* *}$ & $/$ & -0.060 & +0.152 \\
MELD & +0.377 & -0.060 & $/$ & $/$ \\
CTP & +0.024 & +0.152 & $/$ & $/$ \\
\hline${ }^{* *} \mathrm{p}<0.01$ & & & &
\end{tabular}

GHQ-12 - general health questionnaire; CLDQ - chronic liver disease questionnaire; MELD - model of end-stage liver disease; CTP - Child-Turcotte-Pugh score. 


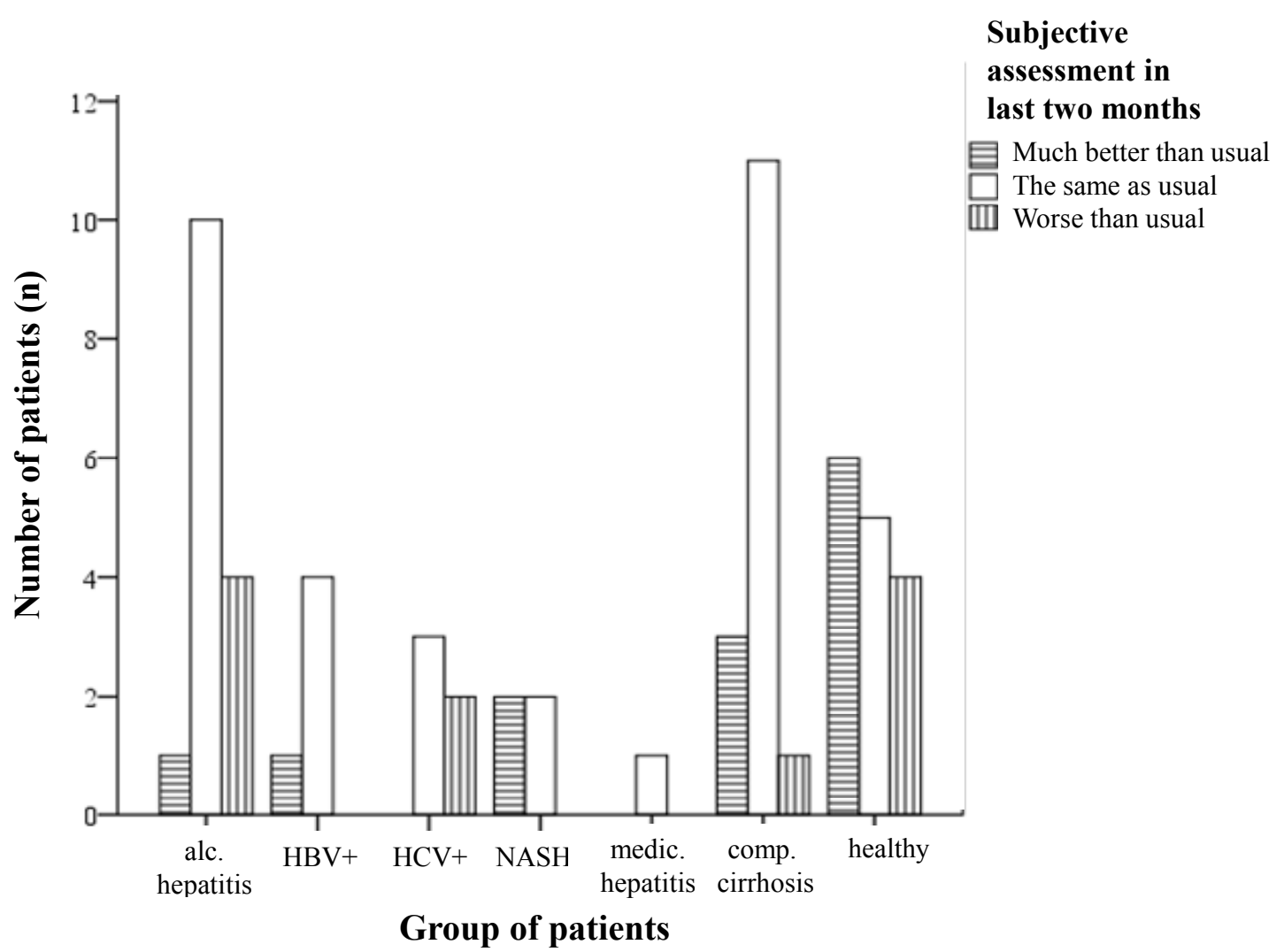

Figure 1. Frequency distribution of participants according to the two-month subjective feeling.

\section{DISCUSSION}

The aim of this study was to test the application simplicity of offered Qol assessment questionnaires developed by $\mathrm{ZCH}$ clinicians, and then to examine whether subjective assessment of respondent's state corresponds to the objective severity of the disease, defined through simple objective and easily processed scores for outpatient settings (in this study the correlation was not registered). Thus, subjective QoL scores correlate between groups (fulfilling even one of the two offered QoL questionnaires is useful), but the subjective and objective scores do not. The explanation may lie in the nature and course of hepatic disease. Average MELD score for CLD, or CTP score for compensated liver cirrhosis, suggested the presence of stable liver disease, in terms of prognosis with a low three-month mortality rate for chronic hepatitis or belonging to the Child A group for the participants with liver cirrhosis with one- and two-year survival rate of $100 \%$ and $85 \%$, respectively. In regard to scores correlation, results show a statistically negative correlation between GHQ12 and CLDQ.
The majority of studies have analyzed viral etiology of CLD followed by alcoholic liver disease, $\mathrm{NASH}$, holestatic liver disease, autoimmune hepatitis, and medicamentous hepatitis [13-15]. There are concordant results in other similar studies regarding the average age of participants, gender, marital status, and educational status [8, 15-17]. Significant predominance of males in different etiologic groups is consistent with the data from literature. Also, our results are in orchestra with literature data, and indicate higher frequency of males within the group of alcoholic liver disease patients. This was not the case with the CLD of other etiology, where the distribution by gender was significantly more uniform compared to the previous studies [16-18].

In this study, the duration of CLD was a little longer (average 5 years) compared with the data from most of the relevant studies [18, 19], although the data relating to the length of the disease might not be reliable enough, because of the oligosymptomatc disease onset. The mean duration of the disease was statistically significantly longer in patients with non-alcoholic hepatitis compared with the alcoholic etiology and patients with liver cirrhosis. 
Average QoL score measured by GHQ12 questionnaire indicates the absence of distress in patients with CLD compared with the control group and also shows the absence of statistically significant intergroup differences. Moreover, an increasing number of patients with "mild" distress was a characteristic for the group of patients with cirrhosis, but without statistical significance in terms of frequency distribution. Our results differ from literature data [14]. According to the most relevant studies, generic QoL score (mainly assessed by SF-36 questionnaire) was significantly lower within the patients with CLD compared with healthy controls, including the studies of Bondini et al. [20], which indicate significantly lower SF-36 scores in patients with cholestatic liver diseases and viral hepatitis $\mathrm{C}$ in comparison with the control group. The study of Younossi et al. [21] pointed out that the SF36 scores were significantly lower in the group of patients with CLD regardless of the etiology, compared with healthy subjects. Svirtlih et al. [22] showed significantly poorer QoL evaluated by SF-12 questionnaire in patients with viral hepatitis compared to the control group, with no significant differences in terms of QoL regarding the etiology of viral hepatitis.

When the values of QoL scores have been compared in other studies, among groups of patients suffering from CLD of different etiology, different results were shown. Study of Afendy et al. [15] shows the lowest scores in the SF-36 questionnaire within the group of patients with NASH compared with the subjects suffering from alcoholic, viral, and chronic cholestatic liver disease. Similar results were shown in the studies of Dan et al. [23] where they estimated QoL by CLDQ questionnaire in the group of patients with NASH and viral hepatitis, with registered CLDQ lowest scores in subjects with NASH, followed by subjects with chronic HCV hepatitis, while the highest score was related to the subjects with chronic HBV hepatitis. Study of Pavic et al. [24] indicated significantly lower SF-16 scores in some questionnaire domains within the patients with chronic HCV hepatitis, compared with the patients with chronic HBV hepatitis. Results of the study of Martin et al. [25] highlighted the impact of etiology of CLD on QoL scores in earlier stages of disease, while the influence of etiology on QoL score gradually disappears as the disease progresses to cirrhosis, similarly to the studies of Kalaitzakis et al. [26] who examined the impact of the etiology of liver cirrhosis on the QoL.

Comparing the QoL of examined patients, using disease-specific questionnaire-CLDQ, we observed a significantly lower score in the "worry" domain in the group of patients with non-alcoholic hepatitis. Scores of other domains CLDQ questionnaire did not significantly differ among the examined groups. In contrast to this, the results of the study Dan et al. [23] show the existence of significantly lower CLDQ scores in all domains except for the "worry" domain in patients with NASH compared with those suffering from viral hepatitis. Study of Parkash et al. [16] has found a significantly lower CLDQ score within the group of patients with cirrhosis compared with those without cirrhosis. Similar results were presented by the Younossi et al. [21] and Che et al. [17], similarly to the severity of CLD with the MELD score from our present study. Majority of published studies pointed out a significant correlation between the severity of the disease and reduced QoL score, assessed by generic CLDQ questionnaires. Study of Gotardo et al. [27] found significantly lower QoL estimated by SF-36 and CLDQ questionnaires in more advanced stages of CLD (MELD score was higher than 15 and the CTP-class C) within the group of patients who are awaiting liver transplants, and they also observed significantly worse scores within the patients with chronic HCV hepatitis compared with liver diseases of other etiologies.

The limitation of our study was the small number of cases analyzed in some groups. Considering the fact that this is a pilot study, which was supposed to justify the use of the offered QoL questionnaires, and objective scores on severity of liver disease, a small number of participants entered the groups, and the study was limited in terms of generalizing the conclusions.

In conclusion, combining analyzed questionnaires (GHQ12, CLDQ) with clinical objective scores might improve diagnostics or timely detect disease worsening, enable following the effect of applied therapy, and help the analysis of novel treatments.The importance of applying QoL questionnaires and objective scores lies in timely detection 
of worsening the hepatic diseases, but also in improving the patient-doctor relationship, which can significantly affect the results of the subjective scores.
Acknowledgements. This work is partially supported by grant No.173033 (to E.R.I) from the Ministry of Science, Republic of Serbia.

Conflict of interest: No conflict of interest.

Introducere. Bolile cronice hepatice (BCH) sunt o cauză importantă de mortalitate şi morbiditate în cadrul populației generale. Obiectivul studiului a fost de a analiza diferențele dintre pacienții $\mathrm{cu} B C H$ şi martori sănătoşi precum şi evaluarea severității BCH folosind două chestionare- GHQ-12 (General health questionnaire 12) şi CLDQ (Chronic liver disease questionnaire).

Materiale şi metode. A fost realizat un studiu transversal pilot în cadrul spitalului Clinic din Zemun în perioada 2014-2015. 60 de participanți au fost impărțiți în 4 grupuri (câte 15 participanți in fiecare grup): pacienți cu hepatită cronică alcoolică, pacienți cu alte hepatite cronice, pacienți cu ciroză hepatică şi 15 martori sănătoşi. Pacienții au completat chestionarele GHQ-12 şi CLDQ şi au fost calculate scorurile MELD şi Child-Turcotte-Pugh (CTP).

Rezultate. Scorurile medii GHQ12 şi CLDQ au fost de10.5 şi respectiv 5.21 \pm 1.1. In privința anumitor scoruri din cadrul chestionarului CLDQ s-a observant o diferență semnificativă între pacienții cu hepatită cronică alcoolică şi cei cu hepatită cronică de altă etiologie. Scorul mediu MELD a fost de $7.42 \pm 2.89$ şi nu a fost semnificativ statistic diferit între grupurile cu hepatită. Scorul mediu CTP a fost de $5.73 \pm 0.88$. A fost observată o asociere semnificativă statistic intre GHQ12 şi $C L D Q(\rho=-0.404, p<0.01)$.

Concluzii. Combinarea chestionarelor GHQ12 şi CLDQ cu scorurile clinice obiective ar putea îmbunătăți diagnosticul şi detecția înrăutățirii bolii precum şi imbunătățirea urmăririi pacienților şi analiza noilor terapii. Importanța aplicării chestionarelor legate de calitatea vieții precum şi a scorurilor clinice obiective este baza detecției rapide a înrăutățirii bolii hepatice dar şi îmbunătățirea relației medic-pacient.

Correspondence to: Zoran Gluvic, MD, PhD

Zemun Clinical Hospital, Clinic of Internal Medicine,

Department of Endocrinology, Diabetes and ITU, School of Medicine, University of Belgrade,

Vukova 9, Belgrade, Serbia

Tel/ Fax: +381113772759/+381113168496

E-mail: zorangluvic@yahoo.com

\section{REFERENCES}

1. SINGH V., LUTHRA S., ELAJAMI TK., WELTY FK. Resolution of NASH with weight loss documented by hepatic MRI. BMJ Case Reports; 2015.

2. The World Health Organization quality of life assessment (WHOQOL): Position paper from the World Health Organization, Social Science \& Medicine 1995; 41(10), 1403-1409.

3. GARRAT A., SCHMIDT L., MACKINTOSH A., FITZPATRICK R. Quality of life measurment: bibliographic study of paient assessed health outcome measures. BMJ Case Reports 2002; 1417.

4. GOLDBERG DP., HILLIER VF. A scaled version of the General Health Questionnaire. Psychological Medicine 1979; 9(1):139-45.

5. SPRANGERS MAG., AARONSON NK. The role of health care providers and significant others in evaluating the quality of life of patients with chronic disease: A review. Journal of Clinical Epidemiology 1992; 45(7):743-60.

6. BAYLISS MS., GANDEK B., BUNGAY KM., DAVID S., HSU M-A., WARE JE. A Questionnaire to Assess the Generic and Disease-Specific Health Outcomes of Patients with Chronic Hepatitis C. Qual Life Res 1998; 7(1):39-55.

7. YOUNOSSI Z., GUYATT G., KIWI M., BOPARAI N., KING D. Development of a disease specific questionnaire to measure health related quality of life in patients with chronic liver disease. Gut 1999; 45(2):295-300. 
8. POPOVIC DD., KOVACEVIC NV., KISIC TEPAVCEVIC DB., TRAJKOVIC GZ., ALEMPIJEVIC TM., et al. Validation of the chronic liver disease questionnaire in Serbian patients. World J Gastroentero 2013; 19(30):4950-7.

9. MCCORMIC PM. Hepatic Cirrhosis, Sherlock's Diseases of the liver and billiary system. In: DOOLEY SJ., LOK A., BURROUGHS KA., HEATHCOTE J., editors. Sherlock's Diseases of the Liver and Biliary System, 12th Edition; WileyBlackwell; 2011:103-20.

10. SARAVANAN P., CHAU WF., ROBERTS N., VEDHARA K., GREENWOOD R., DAYAN CM. Psychological well-being in patients on "adequate" doses of L-thyroxine: results of a large, controlled community-based questionnaire study. Clin Endocrin 2002; 57:577-85.

11. KAMATH PS., KIM WR. The model for end-stage liver disease (MELD). Hepatology 2007, 45(3):797-805.

12. CHOLONGITAS E., PAPATHEODORIDIS GV., VANGELI M., TERRENI N., PATCH D., BURROUGHS AK. Systematic review: the model for end-stage liver disease - should it replace Child-Pugh's classification for assessing prognosis in cirrhosis? Alimentary Pharmacology \& Therapeutics 2005; 22(11-12):1079-89.

13. HÄUSER W., HOLTMANN G., GRANDT D. Determinants of health-related quality of life in patients with chronic liver diseases. Clin Gastroenter Hepatol. 2004; 2(2):157-63.

14. GUTTELING JJ., DE MAN RA., VAN DER PLAS SM., SCHALM SW., BUSSCHBACH JJW, DARLINGTON ASE. Determinants of quality of life in chronic liver patients. Aliment Pharmacol Therap 2006; 23(11):1629-35.

15. AFENDY A., KALLMAN JB., STEPANOVA M., YOUNOSZAI Z., AQUINO RD., BIANCHI G., et al. Predictors of healthrelated quality of life in patients with chronic liver disease. Aliment Pharmacol Therap 2009; 30(5):469-76.

16. PARKASH O., IQBAL R., JAFRI F., AZAM I., JAFRI W. Frequency of poor quality of life and predictors of health related quality of life in cirrhosis at a tertiary care hospital Pakistan. BMC Research Notes 2012; 5: 446.

17. CHE YH., YOU J., CHOUNGSUVIVATWONG V., LI L., SRICPLUNG H., YAN YZ., et al. Dynamics and Liver Disease Specific Aspects of Quality of Life Among Patients with Chronic Liver Disease in Yunnan, China. Asian Pac J Cancer Prev 2014; 15(12): 4765-71.

18. CHANG S-C., YANG S-S., CHANG C-C., LIN C-C., CHUNG Y-C., LI T-C. Assessment of health-related quality of life in antiviral-treated Taiwanese chronic hepatitis C patients using SF-36 and CLDQ. Health Qual Life Outcomes 2014; 12:97.

19. THIELE M., ASKGAARD G., TIMM HB., HAMBERG O., GLUUD LL. Predictors of Health-Related Quality of Life in Outpatients with Cirrhosis: Results from a Prospective Cohort. Hepatitis Res Treat 2013; 2013.

20. BONDINI S., KALLMAN J., DAN A., YOUNOSZAI Z., RAMSEY L., NADER F., et al. Health-related quality of life in patients with chronic hepatitis B. Liver Int 2007; 27(8):1119-25.

21. YOUNOSSI ZM., BOPARAI N., PRICE LL., KIWI ML., MCCORMICK M., GUYATT G.Health-related quality of life in chronic liver disease: the impact of type and severity of disease. Am J Gastroenterol 2001; 96(7):2199-205.

22. SVIRTLIH N., PAVIC S., TERZIC D., DELIĆ D., SIMONOVIC J., GVOZDENOVIC E. Reduced quality of life in patients with chronic viral liver disease as assessed by SF12 questionnaire. J Gastrointestin Liver Dis 2008; 17(4):405-9.

23. DAN AA., KALLMAN JB., WHEELER A., YOUNOSZAI Z., COLLANTES R., BONDINI S., et al. Health-related quality of life in patients with non-alcoholic fatty liver disease. Alimen Pharmacol Therap 2007; 26(6):815-20.

24. PAVIC S., DELIC D., SIMONOVIC J., SVIRTLIH N. Quality of life in patients with chronic hepatitis C. Srp Arh Celok Lek 2011; 139(3-4):165-9.

25. MARTIN LM., DAN AA., YOUNOSSI Z. Measurement of health-related quality of life in patients with chronic liver disease. Liver Transplantation 2006; 12(1):22-3.

26. KALAITZAKIS E., JOSEFSSON A., BJÖRNSSON E. Type and etiology of liver cirrhosis are not related to the presence of hepatic encephalopathy or health-related quality of life: a cross-sectional study. BMC Gastroenterol 2008; 8(1):46.

27. GOTARDO DRM., STRAUSS E., TEIXEIRA M-CD., MACHADO MCC.Liver transplantation and quality of life: relevance of a specific liver disease questionnaire. Liver Int 2008; 28(1):99-106.

Received January 16, 2017 